\title{
Decision-Making Strategies in Design Meetings
}

\section{Erin Friess}

Carnegie Mellon University

English Department

5000 Forbes Ave.

Pittsburgh, PA 15213 USA

efriess@andrew.cmu.edu

\begin{abstract}
This project aims to further our understanding of the practice of user-centered design (UCD) by observing the argumentation strategies used by designers in faceto-face meetings in the critical periods between usability research and prototype iteration. In order to conduct such an investigation, I recorded ten meetings of graduate student designers charged with redesigning documents for the United States Postal Service. I then used discourse analysis techniques to determine how the designers used findings from research phases as evidence to support proposed design decisions in
\end{abstract}

Copyright is held by the author/owner.

CHI 2007, April 28-May 3, 2007, San Jose, California, USA. ACM 978-1-59593-642-4/07/0004. meetings concerning prototype alterations. Results show that these designers overwhelmingly do not support their design decisions with specific evidence from usability studies. This neglect of research-based evidence may indicate that these novice UCD designers may resort to designer-centric design behaviors in decision-making periods. My analysis will focus on the rhetorical reasons why designers may avoid researchbased evidence.

\section{Keywords}

User-centered design (UCD), usability studies, argumentation, discourse analysis, empirical study, design process theory, design pedagogy

\section{ACM Classification Keywords}

H.5.2 User Interfaces: theory and methods, usercentered design, evaluation/methodology

\section{Introduction}

For decades, user-centered design (UCD) has been hailed as the "key to product usefulness and usability" and "an effective approach to overcoming the limitations of traditional system-centered design" [4]. While there are slight variations in models of UCD, all approaches include two steps: 1) conduct some kind of research with people who might use the end design, 
and 2) incorporate those research findings into the design solution.

Yet, how do we know if, in fact, novice designers are incorporating the knowledge gathered in user research into the iterations produced throughout the design process? Surprisingly little research investigates the space between research and design with an emphasis on designer communication. Of most pertinence to this dissertation study, Sugar found that "although designers claimed they benefited from their usability sessions, they made minimal changes to their prototypes afterward" [6]. Further, Sugar concludes that "it is dangerous to rely on novice designers' insistence that their usability sessions are beneficial and they are indeed practicing user-centered design" [ibid].

Extending upon Sugar's work, which used retrospective interviewing techniques, I borrow techniques from argumentation and discourse analysis to look directly at what designers say to fellow designers during face-toface decision-making meetings. Specifically, I look closely at the types of evidence used by designers in these decision meetings to support their design decisions. I believe that a close analysis of the language these novice designers themselves employ during actual decision-making meetings may shed some much-needed light on how novice designers learn to (or don't) incorporate usability findings into their discussions concerning potential design changes.

\section{Research Questions}

My research questions include:
- Do these novice designers support claims with evidence?

- What kinds of evidence do they use in face-to-face meetings?

- What are the patterns of evidence?

- What might these patterns mean for pedagogical theories of UCD?

- What rhetorical reasons might the designers have for using evidence in the ways they do?

\section{Methods}

In order to study the ways designers use evidence in decision-making meetings, I observed a naturallyoccurring group of approximately 18 -full time graduate student designers at a highly selective, private research-oriented university. In January 2002, the design department entered into a contract with the United States Postal Service (USPS) that charged the design team, under the direction of a faculty principal investigator, with re-envisioning several documents, including the USPS' central procedural and legal document. According to the statement of work, 35\% of the designers' work was to be researching users and testing prototypes. According to Mao, et al, this dedication to research and testing is generally more than in typical design projects [4].

I audio recorded the biweekly full team meetings of the designers for one year. After each meeting, I transcribed the spoken exchanges that occurred within the meeting. I coded each transcript for the claims (or "a standpoint regarding a subject") and evidence (or "certain facts on which the claim is based") [7]. For the analysis of evidence, I coded 3 support categories established by Kuhn in Skills of Argument [3]. 
Fact-Based Evidence

Fact-based evidence is separate from the claim itself and includes at least an attempt by the participant to support the claim by pointing to a source of origin (such as a usability study, a written text, or a perceived authority figure like a teacher or field expert) outside the speaker's self. Example: "We should use, I don't know, at least a 10/12 typeface...'cause remember that Bob, um, Bob didn't like that small typeface we used on the $\mathrm{P} 2^{1}$."

\section{Non-evidence}

Non-evidence is an attempt by a designer to support a claim simply by repeating the claim. Example: "...we shouldn't use a small typeface because it's small."

\section{Pseudoevidence}

Pseudoevidence is any attempt by a designer to support a claim that could not be coded as nonevidence and that did not point to some source outside of themselves. Typically, pseudoevidence took the form of a hypothetical story that did not exist outside of the speaker's self. Example: "I think it would be a mistake if we have a small typeface because it'll make it hard especially for the elderly to read it."

\section{Results}

The reliability of the coding scheme, coded by two independent raters, was 0.71 (Cohen's Kappa). The designers made many claims without any support whatsoever. On average, only $60 \%$ of the claims made during the meeting were accompanied by any kind of

\footnotetext{
${ }^{1}$ All of the examples were taken from the group meetings.
}

support, be it fact-based evidence, non-evidence, or pseudoevidence.

Additionally, the designers' use of pseudoevidence far surpasses the use of fact-based evidence and nonevidence combined. In the $40 \%$ of the time that any support is given at all, that support will be in the form of pseudoevidence $70.5 \%$ of the time. Fact-based evidence is used $27.6 \%$ of the time, while non-evidence is used $3.2 \%$ of the time.

\section{Analysis}

The novice designers in this case study were charged by their client, the USPS, to dedicate $35 \%$ of their time to research and usability studies-activities that would seemingly produce ready-made fact-based evidence. Yet, when it came time to actually justify their design decisions, the designers overwhelmingly used pseudoevidence over fact-based evidence by a margin of nearly $2: 1$.

I find this use of pseudoevidence startling. This group of design students in a highly selective graduate program created very well received documents, but their argumentation strategies often ignored UCDproduced fact-based evidence. Does this mean that these novice designers are poor reasoners? In my dissertation, I plan to explore reasons why these designers gravitate to pseudoevidence, as well as what the ramifications these patterns of evidence may have on the field of design.

- Face, according to Goffman, is "an image of self delineated in terms of approved social attributes," and every interaction includes face-work, which involves the members attempting to maintain face and save face, 
not only individually, but for the entire group involved in the communication [2]. Could these designers be using pseudoevidence to avoid a potential facethreatening act toward a fellow designer?

- Professional identity concerns the manner in which the designers individually situate themselves as justified members of the group by drawing on individual expertises and behavior [1]. Could pseudoevidence, which seems to draw upon designers' experience rather than the shared fact-based evidence, be a way for designers to stand out from the others?

- Distributed cognition focuses on the shared social aspects of cognition, unlike traditional argument theory that focuses on the cognitive behaviors of the individual. Could it be that, despite the collectively shared usability findings, the typically narrative structure of pseudoevidence is somehow easier for groups at the group level to internalize?

- Designer-centered design allows designers to rely upon their own beliefs and intuitions. Could pseudoevidence, which doesn't draw upon anything outside the speaker's self, be revealing that students misunderstand UCD?

- Additionally, what might this mean for educators who are instructing students in UCD? What might this mean for UCD and design rationale in the field of design? To what extent could computer-supported collaborative work tools help (or hinder) designers to include specific reference to usability findings in their talk?

\section{Significant Contributions}

This ethnographic study allows for a deepened understanding of what actually occurs in the talk of these novice designers during the space between usability and iteration. Additionally, it provides a framework for the analysis of the types of support that designers use in their decision-making talk (although this framework may need revision). This study also reveals that educators of UCD may need to take a critical look at the pedagogical theories and instructional practices associated with UCD. The analysis phase of my dissertation will help to determine the reasons why pseudoevidence is used over factbased evidence during periods of decision-making, and if, in fact, this use of pseudoevidence is at all problematic.

\section{References}

[1] Dannels, D.P. Learning to be professional: Technical classroom discourse, practice, and professional identity construction. Journal of Business and Technical Communication, 14 (1). 5-37.

[2] Goffman, E. On face-work: An analysis of ritual elements in social interaction. In Interactional Ritual: Essays on Face-to-Face Behavior. Pantheon Books, New York, 1967.

[3] Kuhn, D. The skills of argument. Cambridge UP, New York, 1991.

[4] Mao, J.-Y.; Vrandenberg, K.; Smith, P.W.; Carey, $\mathrm{T}$. The state of user-centered design practice. Communications of the ACM, 48 (3). 105-109.

[5] Salomon, G. Distributed cognitions: psychological and educational considerations. Cambridge UP; New York, NY, 1993.

[6] Sugar, W.A. What is so good about user-centered design? Documenting the effect of usability sessions on novice software designers. Journal of Research on Computing in Education, 33 (3). 235-250.

[7] Toulmin, S. The uses of argument. Cambridge UP, New York, 1958. 